\title{
Exploring the Relationship Between Personality Traits and TPACK-Web of Pre-service Teacher
}

\author{
M. Anas Thohir \\ Universitas Negeri Malang, Indonesia \\ ORCID: 0000-0002-4865-253X \\ Lia Yuliati \\ Universitas Negeri Malang, Indonesia \\ ORCID: 0000-0002-9361-3505 \\ Erif Ahdhianto \\ Universitas Negeri Malang, Indonesia \\ ORCID: 0000-0003-2354-7079 \\ Esti Untari \\ Universitas Negeri Malang, Indonesia \\ ORCID: 0000-0002-0179-7520 \\ Fitri April Yanti \\ Universitas Bengkulu, Indonesia \\ ORCID: 0000-0003-1169-8806
}

\begin{abstract}
The successes of web design by learning relates to the pre-service teachers' personality. Unfortunately, the relationship between personality and pre-service teachers' technological pedagogical content knowledge related Web (TPACK-Web) still uncertain. The main objective of this study was to explore the relationship between the Five-Factor Model (FFM) of personality and TPACK-Web of the pre-service teacher in Indonesia ( $\mathrm{N}=309$ ). To examine the correlation among two packages of variables, descriptive statistic, bivariate correlation, and Partial Least Squares-Structural Equation Modelling (PLS-SEM) was applied. The finding presented that the correlation between FFM of personality and TPACK-Web was significant. The most important finding suggested that Agreeableness, Conscientiousness, and Openness had a direct effect on the core of TPACK-Web bases (WK, PK, CK), and WPK to WPACK had the strongest effect. Finally, the implication of this study is provided along with suggestions.
\end{abstract}

Keywords: five factor model, TPACK-web, pre-service teacher, PLS-SEM

\section{INTRODUCTION}

Learning by design is an emerging pedagogic approach for enhance pre-service teacher's Technological Pedagogical and Content Knowledge in web learning design or TPACK-Web. This offers advantages for preservice teacher of communication, synchronization, social dynamic collaboration, learning-improvement, knowledge-sharing, multimedia-application, and cost-effectiveness (Jafari Navimipour \& Zareie, 2015; Mishra \& Koehler, 2006; Owston, 1997; Seal \& Przasnyski, 2001; Sife, Lwoga, \& Sanga, 2007). Pre-service 
teachers also create a new culture of learning and the belief with others to use and design Web (Chai et al., 2017). For the success of this goal, personalized learning supports is an important component to optimalization of the course (Wu et al., 2019; Xie et al., 2019). Moreover, TPACK is an ill-structured, complex, and disorder to design meaningful integration instruction of technology (Redmond \& Lock, 2019).

The success of a pre-service teacher course involves what persona is required in web design. Persona can be seen from how personality traits are related to the artifacts they design (Anvari et al., 2017). In addition, Chua and Jamil (2013) identified that personality and organization were the main factors of teacher's TPACK. However, studies about the type of pre-service teacher's personality trait relate TPACK is limited (Scherer et al., 2018; Thohir et al., 2020). In Indonesia context, the personality is one of four core competencies for a teacher, the others pedagogy, subject matter, and social competence (Chang et al., 2014, p. 2). The personality also interpreted as various means, for instance, attitude toward web-based learning was defined "the motivation and the willingness" in integrating the web into instruction (Kavanoz et al., 2015). This also was detected that personality variable related to teachers' self-efficacy in teaching effectiveness (Klassen \& Tze, 2014).

Five-factor model (FFM) of personality traits have an enormous potential to promote the association of preservice teachers' TPACK as a individuals' personality trait related a web media use (Correa et al., 2010). Those also are a stabiles theory in showing general teacher personality trait. McCrae \& John (1991) initially developed to provide the basic personality (conscientiousness, openness to experience, neuroticism, extraversion, and agreeableness) as a guide to the comprehensive assessment for education and other organizations. The factors can be an important indicator to support education policy in preparing teachers in the higher teacher (Corcoran \& O'Flaherty, 2018; De Jong et al., 2014; Jamil et al., 2012; Njiku et al., 2021; Ozudogru \& Ozudogru, 2019). Recently, researchers have paid attention to correlate personality and technological integration (Barnett et al., 2015; Bhagat et al., 2019; A. Cohen \& Baruth, 2017; Kober \& Neuper, 2013; Lane, 2012; Walkowiak et al., 2015). However, the pre-service teachers' FFM of personality and their WPACK have yet to be confirmed. Cohen and Baruth (2017) predicted that Openness and Conscientiousness become factoring students satisfy in the online course. Another research shows that Agreeableness become more strongly predictor correlated instructional design (Bhagat et al., 2019). In addition, those are still need to deep exploration the relations of personality with technology integration. Thus, the purpose of this study is to explore the correlation of the pre-service teachers' personality traits and the set of TPACK-Web components.

\section{Technological Pedagogical Content Knowledge-Web Framework}

TPACK and TPACK-Web look alike, but they differ in two variants, namely web substitution and attitudes (Gökçearslan et al., 2016). TPACK was proposed by Mishra \& Koehler (2006) with integrating technological knowledge into Shulman's (1986) PCK. This framework provides evidence of interception between pedagogical knowledge (PK), content knowledge (CK), and TK to become; PCK, technological pedagogical knowledge (TPK), technological content knowledge (TCK), and TPACK (Celik et al., 2014; Pamuk et al., 2015). Whereas, TPACK-Web was introduced by Lee and Tsai (2010) as a part of the expanding TPACK framework that was needed by the pre-service teacher to design and implement web in classroom interaction. This framework has impacted other researches by developing own instruments (Chai et al., 2016; Horzum \& Canan Gungoren, 2012; Kavanoz et al., 2015). It is constructed by Lee and Tsai (2010) into seven components; Web knowledge (WK), content knowledge (CK), pedagogy knowledge (PK), pedagogical content knowledge (PCK), Web-content knowledge (WCK), Web-pedagogical knowledge (WPK), Web-pedagogical content knowledge (WPACK). Then, they revised the TPACK-Web questionnaire through experts consisting of Webgeneral (WG), Web-communication (WC), WPK, WCK, WPACK, and attitude toward Web. The instrument of WPACK has a high level of validity and reliability for WK, WCK, and WPACK (M.-H. Lee \& Tsai, 2010). However, PK and PCK are not allowed in the questionnaire that may cause WPK unreliable. This might contradict to Shulman (1986) that constructed the PCK with involving PK (Brantley-Dias \& Ertmer, 2013). Therefore, other studies included PK, PCK, and WPK (Kavanoz et al., 2015; Zhou et al., 2017). 


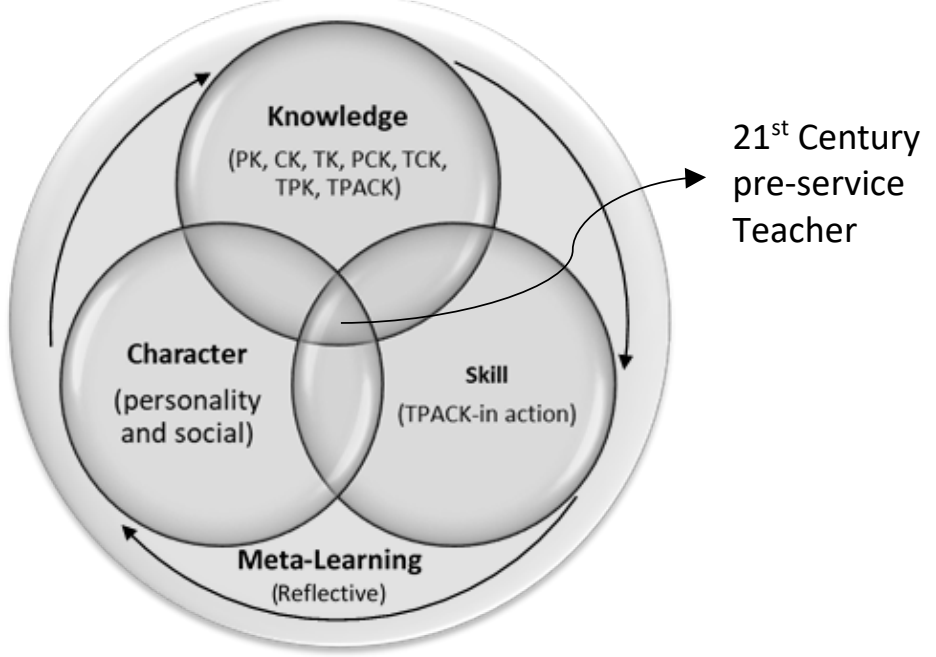

Figure 1. 4D-TPACK framework (Thohir et al., 2020)

Also, most of TPACK researchers emphasized the knowledge dimension as fundamental of the pre-service teacher, whereas WPACK offered other dimensions (e.g., attitude toward web). The research shows that WPACK has a positive factor-related attitude toward web instruction (Kavanoz et al., 2015), and it supported the level of science teacher's TPACK-Web (Horzum \& Gungoren, 2012). Another research provides that TPACK-Web relate to attitude as predictor the individual innovative (Gökçearslan et al., 2016). While most literature of TPACK-Web has explained the construction and the factors of its components, few of the researchers related TPACK-Web components and another dimension. Thohir et al. (2020) explained that TPACK has 4 dimensions, including knowledge, skills, social character and personality, and meta learning as shown in Figure 1.

\section{Pre-service Teachers' Five Factor Model of Personality Traits}

The researchers have addressed the factors of sophisticating personality to uncover more appropriate that represent trait of a pre-service teacher. FFM of personality was proposed by McCrae and John (1991) with five fundamental dimensions (Extraversion, Agreeableness, Conscientiousness, Neuroticism, and Openness), and education should be able to find the model. Moreover, a teacher's personality can present job performance (Bowles et al., 2014). Therefore, many researchers examined the teachers' personality in performance (Corcoran \& O'Flaherty, 2018; Ikpi et al., 2014; Jamil et al., 2012; Scheepers et al., 2014; Ulug et al., 2011). Djigić et al. (2014) defined each factor as; Openness is a trait regarding intellectual, diverse, adaptable, trying, and creative; Conscientiousness is awareness to discipline towards goals, and holding strong principles; Extraversion is a part of personality trait related to the social activity, such as gregariousness, assertiveness, and garrulousness; Agreeableness is a trait of personality related to love, generosity, and believable; and Neuroticism is a factor of personality that makes a person different in emotional stability, such as sadness, fear, angry, nervous, and gilt.

Recently, researchers attempted to unpack FFM personality trait in the pre-service teacher (Biermann et al., 2015; Corcoran \& O'Flaherty, 2018; De Jong et al., 2014; I. R. Lee \& Kemple, 2014). When pre-service teachers are adapting to the environment, they are studying three parts of FFM personality trait, namely Conscientiousness, Agreeableness, and Extraversion related the teacher performance (Corcoran \& O'Flaherty, 2018). Another research argued that Openness is a strong predictor that links to pre-service teacher's practice (I. R. Lee \& Kemple, 2014). Moreover, all components of FMM personality trait associated with pre-service teacher's teaching skill particularly Extraversion (Biermann et al., 2015). Perkmen et al. (2018) argued that pre-service teachers' personality plays important roles for all factors in teacher behavior. 


\section{Relationship FFM and TPACK-Web}

Pre-service teachers need a specific personality to design and implement technology in instructional learning. For example, Al-Ismail et al. (2017) invented that different students' attitudes toward m-learning dependent on personality, especially Neuroticism and Agreeableness. Extraversion refers to how a student-teacher used technology to do the social activity or self-activity, openness implies how student-teacher prefer to inspire or apply, agreeableness refer to a student-teacher that seems believing or doubtful, and conscientiousness is a student teacher's preference to organize or disorganize. Moreover, Barnett et al. (2015) explained two of FFM personality traits (conscientiousness and neuroticism) that directly correlated with technology system use. Jia et al. (2016) also reported that was a correlation between extraversion and openness.

Previous empirical studies show that web related to personality inventories. Correa et al. (2010) have explored user personality and social media on the web that shows a positive correlation, particularly extraversion, neuroticism, and openness. Wu et al. (2019) reported that conscientiousness has a positive impact on web student user activity, and openness to experience influence to chat room and discussion forum. Other researchers demonstrated that users of the web owner comparing with reference group was significantly different, especially extraversion, openness, and conscientiousness (Marcus et al., 2006). Although the FMM personality traits and TPACK-Web do not directly illustrate the assertion, those researches might show the linkage both scales as Scherer et al. (2018) recommended. Therefore, the purposes of the study were:

1. To identify the Indonesian pre-service teachers' TPACK-Web and FFM of personality.

2. To investigate the TPACK-Web construct based on web submission of PCK like TPACK framework theoretically defined.

3. To investigate the model of correlation between FFM personality variables and TPACK-Web components.

\section{METHOD}

\section{Research Context and Participant}

The procedure of the study had two-stage processes. The first stage was designing the instrument TPACK-W dan FFM of personality. In this stage, the instrument was reviewed by five experts to get opinion and to assess the instrument. Based on advising of experts, the instrument was revised and carried out validate the instrument with 130 pre-service teachers from Indonesia University. Finally, the items of the instrument selected based on dimension reduction process.

In the second stage, data were gathered from 309 pre-service teachers at nine large universities and highlevel accreditation in Indonesia. The university was randomly nominated for data collecting. This data was used to analyse the connection of pre-service teachers' TPACK-Web and FFM of personality trait. To ensure the result, data analysed Structural Equation Modelling (SEM) developed from TPACK-Web and FFM theory (see Figure 2).

Data was collected from pre-service teachers in the department of physics education (52\%), Elementary (31\%), and Preschool Education (17\%). Mostly, the participants were female $(n=234)$ and in early twenty ages, with the range 20-23 years $(n=262)$. The distribution of pre-service teacher related the culture was Javanese (85\%), Nusa Tenggara Barat (10\%), Sumatera (3\%), Sulawesi (2\%), and others $(5 \%)$. The program of participants was eight semesters along with four-year teacher education. They joined several education courses, including educational psychology, models of teaching, classroom assessment, and teaching practicum. They also took content professional courses according to their respective fields. In the technology course, they took office application course and multimedia, including web media. In the first and second year, they had to join the moral development and religious education. 


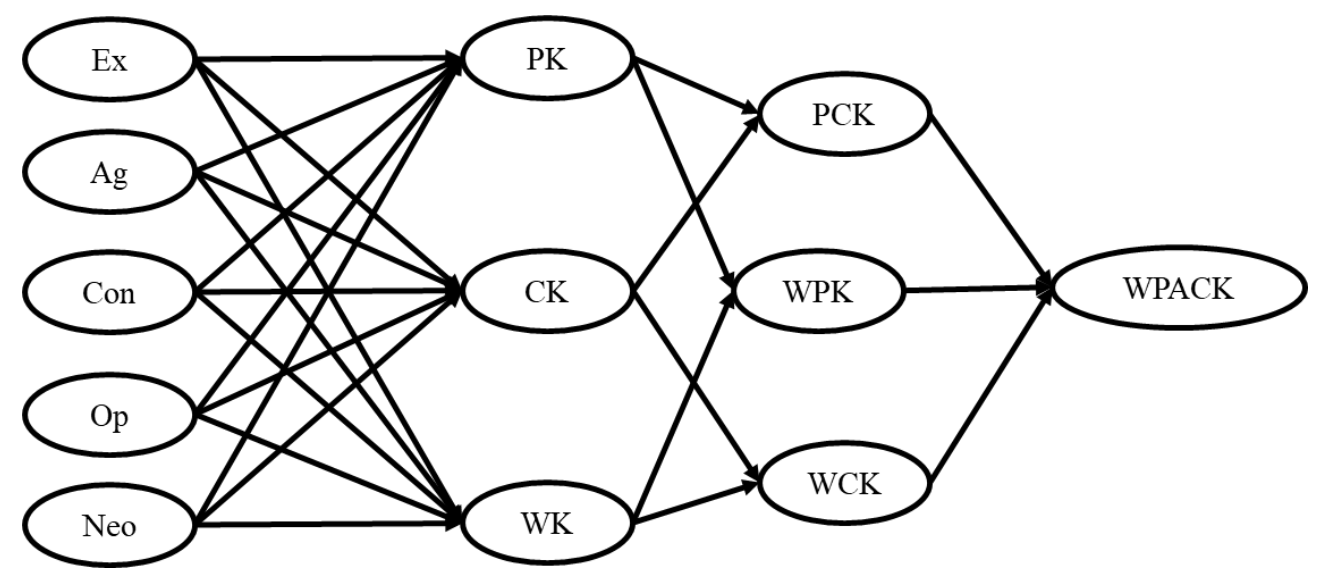

$\mathrm{Ex}=$ Extraversion $\mathrm{Ag}=$ Agreeableness, Con $=$ Conscientiousness, $\mathrm{Op}=$ openness, $\mathrm{Neo}=$ Neuroticism, $\mathrm{PK}=$ pedagogical knowledge; $C K=$ content knowledge; $W K=$ Web-knowledge; $P C K=$ pedagogical content knowledge; $W P K=W e b-$ pedagogical knowledge; $W C K=$ Web-content knowledge; and WPACK = Web-pedagogical content knowledge

Figure 2. Initial corelated TPACK-Web and FFM of personality traits

\section{The Instruments Development}

The survey study addressed to explore related WPACK and personality in technology integration. Anonymous pre-service teachers were asked to complete the questionnaire by filling multiple choices of Likert scales. They could accomplish the items by paper-based and online web-based questionnaire. It contains two major variables, namely WPACK and FFM personality traits (see Appendix 1). Based on the previous research, those were designed as follows.

\section{The questionnaire of pre-service teachers' WPACK}

The items were adapted from (M.-H. Lee \& Tsai, 2010) that explored twenty items of WPCK/WPACK with five indicators (Web-general, Web-communicative, Web-CK, WPACK, and Attitude) because its construction supported this study such as, knowledge to "copy text on the Web" and to "use Web technology to enhance teaching". For the comprehension items of TPACK, this study also modified survey item of Schmidt et al. (2009), especially the structure item of PK, and PCK, such as knowledge to "use a wide range of teaching approaches in a classroom setting" and "select effective teaching approaches to guide student thinking and learning ...". The scaling of this questionnaire was 5 -point Likert-kind ranging from $1=$ strongly disagree to 5 = strongly agree.

The design of instrument involved expert review, analytical reliability, and dimension reduction process. Before the data was collected, the questionnaire was reviewed by five lecturers and three pre-service teachers to avoid the ambiguous language and to achieve comprehension. This validation calculation used Aiken (1985), and the range obtained was between .95 to .85 . Reliability also was calculated from this the gathering of data for each sub-scale. In Table 1, the Cronbach's alpha and composite reliability of TPACKWeb instrument were calculated. However, the experts suggested reducing the factor by combining Webgeneral and Web-communicative because that referred to the origin of TPACK. In addition, the factor analysis was conducted to reduce and fit the factor using second-order confirmatory factor analysis (2nd-order CFA), which expressed high strong model, $\chi 2(1)=154.01, p=.62, \mathrm{CFI}=1.00, \mathrm{TLI}=1.00, \mathrm{RMSEA}=.00$. Factor loading of one-factor model ranged between .93 and .62 (see Appendix 1).

\section{The questionnaire FFM of personality traits}

This scale initially was selected from John and Srivastava (1999) that designed the original work of big five taxonomies. To adjust of technological context, the recent research (Barnett et al. 2015) also was adopted to relate FFM personality traits and WPACK in seventeen items along five sub-scale: agreeableness (e.g., I am sometimes rude to others), extraversion (e.g., I am a friendly person), openness (e.g., I am a person who is curious about many different things), neuroticism (e.g., I am a person who keeps calm in a tense situation), 
Table 1. Reliability of the TPACK-Web and Personality instruments

\begin{tabular}{lcc}
\hline Indicators & Cronbach's $\alpha$ & Composite reliability \\
\hline PK & .83 & .90 \\
CK & .81 & .88 \\
WK & .75 & .90 \\
PCK & .86 & .89 \\
WPK & .93 & .92 \\
WCK & .70 & .93 \\
WPACK & .90 & .92 \\
Agreeableness & .69 & .87 \\
Extraversion & .78 & .79 \\
Openness & .79 & .88 \\
Neuroticism & .88 & .70 \\
Conscientiousness & .81 & .88 \\
\hline
\end{tabular}

and conscientiousness (e.g., I would rather endure until completing of the task). Like WPACK questionnaire, all items were assessed with 5 -point of Likert scales from $1=$ strongly disagree to $5=$ strongly agree. The reliability of the questionnaire was calculated by using Cronbach's alpha and composite reliability as shown in Table 1. One-factor model of FFM personality trait was conducted through CFA-SEM, which confirmed high value, $\chi 2(2)=82.59, p=.16, C F I=1.00, T L I=1.00, R M S E A=.02$. Factor loading of one-factor model ranged between .93 and .72 .

\section{Data Analysis}

Partial Least Squares-Structural Equation Modelling (PLS-SEM) was employed to examine the relation among FFM personality traits and WPACK latent variables. As with the previous review (Ringle et al., 2012) one-third of researches chose the method to measure the latent variable. PLS-SEM also was recommended to predict the target constructs of the model (Alt, 2018). However, this is an essential statistical modelling technic to explore the model developed (Joseph et al., 2017). This study offered alternative constructs by using SmartPLS 3.

\section{FINDING}

\section{Pre-service Teachers' TPACK-Web and FFM of Personality Traits}

Descriptive statistic was conducted to know pre-service teachers' TPACK-Web and FFM of personality traits (see Table 2). For TPACK-Web, all variables achieved the mean over than 3 points. Pre-service teacher scored the highest scale on the PK $(M=3.92, S D=.58)$ but lowest on WK $(M=3.31, S D=.82)$. In FFM of personality traits, almost scales of personality have over 3, only one get fewer ones. The greatest Agreeableness (M $=3.89, \mathrm{SD}=.64$ ) shows that pre-service teacher regarded as a helping, forgiving, and caring person but the lowest on Neuroticism ( $\mathrm{M}=2.83, \mathrm{SD}=.82$ ) like depression and worries person. 
Table 2. The pre-service teachers' attainment of WPACK and FFM of personality traits

\begin{tabular}{lccc}
\hline Construct & $\mathrm{N}$ & Mean & SD \\
\hline PK & 309 & 3.92 & .58 \\
CK & 309 & 3.78 & .59 \\
WK & 309 & 3.31 & .82 \\
PCK & 309 & 3.70 & .59 \\
WPK & 309 & 3.58 & .72 \\
WCK & 309 & 3.70 & .66 \\
WPACK & 309 & 3.57 & .68 \\
Openness & 309 & 3.40 & .65 \\
Conscientiousness & 309 & 3.67 & .57 \\
Extraversion & 309 & 3.11 & .61 \\
Agreeableness & 309 & 3.89 & .64 \\
Neuroticism & 309 & 2.83 & .82 \\
\hline PK
\end{tabular}

PK = pedagogical knowledge; $C K=$ content knowledge; $W K=$ Web-knowledge; PCK = pedagogical content knowledge; WPK = Web-pedagogical knowledge; WCK = Web-content knowledge; and WPACK = Web-pedagogical content knowledge

Table 3. Bivariate correlations between TPACK-Web and FFM of personality traits

\begin{tabular}{|c|c|c|c|c|c|c|c|c|c|c|c|c|}
\hline Variable & 1 & 2 & 3 & 4 & 5 & 6 & 7 & 8 & 9 & 10 & 11 & 12 \\
\hline 1. PK & 1.00 & & & & & & & & & & & \\
\hline 2. $\mathrm{CK}$ & $.48^{* *}$ & 1.00 & & & & & & & & & & \\
\hline 3. WK & $.23 * *$ & $.29 * *$ & 1.00 & & & & & & & & & \\
\hline 4. PCK & $.49 * *$ & $.54 * *$ & $.37 * *$ & 1.00 & & & & & & & & \\
\hline 5. WPK & $.39 * *$ & $.37^{* *}$ & $.46 * *$ & $.47^{* *}$ & 1.00 & & & & & & & \\
\hline 6. WCK & $.37 * *$ & $.44 * *$ & $.44 * *$ & $.44 * *$ & $.62 * *$ & 1.00 & & & & & & \\
\hline 7. WPACK & $.39 * *$ & $.38^{* *}$ & $.45^{* *}$ & $.48^{* *}$ & $.66^{* *}$ & $.60 * *$ & 1.00 & & & & & \\
\hline 8. Openness & $.29 * *$ & $.29 * *$ & $.17 * *$ & $.26 * *$ & $.29 * *$ & $.24 * *$ & $.31 * *$ & 1.00 & & & & \\
\hline 9. Conscientiousness & $.28^{* *}$ & $.32 * *$ & $.20 * *$ & $.34^{* *}$ & $.32 * *$ & $.33 * *$ & $.30 * *$ & $.46^{* *}$ & 1.00 & & & \\
\hline 10. Extraversion & .01 & .04 & .08 & .07 & .03 & .05 & .02 & $.12^{*}$ & .05 & 1.00 & & \\
\hline 11. Agreeableness & $.31 * *$ & $.29 * *$ & $.14 * *$ & $.36 * *$ & $.31 * *$ & $.21 * *$ & $.27^{* *}$ & $.34 * *$ & $.36 * *$ & .07 & 1.00 & \\
\hline 12. Neuroticism & -.02 & -.04 & .03 & .00 & -.05 & .03 & -.04 & -.03 & -.05 & $.38 * *$ & -.06 & 1.00 \\
\hline
\end{tabular}

PK = pedagogical knowledge; $C K=$ content knowledge; $W K=$ Web-knowledge; PCK = pedagogical content knowledge; WPK = Web-pedagogical knowledge; WCK = Web-content knowledge; and WPACK = Web-pedagogical content knowledge

**Correlation is significant at the 0.01 level (2-tailed)

*Correlation is significant at the 0.05 level (2-tailed)

\section{The Relationship of Pre-service Teacher's WPACK and FFM of Personality Traits}

Table 3 displays the bivariate correlation of TPACK-Web and FFM of personality traits. The relationship among TPACK-Web components was significant, particularly WPK and WPACK that had a strong correlation $(r=.66, p<.01)$. Meanwhile, the correlation among FFM of personality traits was significant, except extraversion and neuroticism variable. Consequently, the Extraversion and Neuroticism factor was omitted in future analysis.

To examine the interrelationship between TPACK-Web and FFM of personality traits as given in Figure 2, PLSSEM was conducted by SmartPLS 3. This path model contains three factors of personality traits as exogenous and the seven of TPACK-Web components as endogenous Figure 3. The evaluation of the path model build was examined by the Variance Inflation Factor (VIF), the coefficient determination (R square), and effect size (f square). First, the result illustrated that All VIF value of the inner and outer model were found less than 3 , below the threshold of 5 (Joseph et al., 2017). Then, R2 was shown to provide the model of fit displayed under the ellipse of endogenous latent variables. The result showed that $88 \%$ of the variant in WPACK variable was explained by the model. Next, to represent of effect size, this study referred to Cohen (1988, $\mathrm{p}$. $24)$ that the largest effect size was on WCK $\rightarrow$ WPACK $(f 2=.843)$ as shown in Table 4. Indirect relationship 


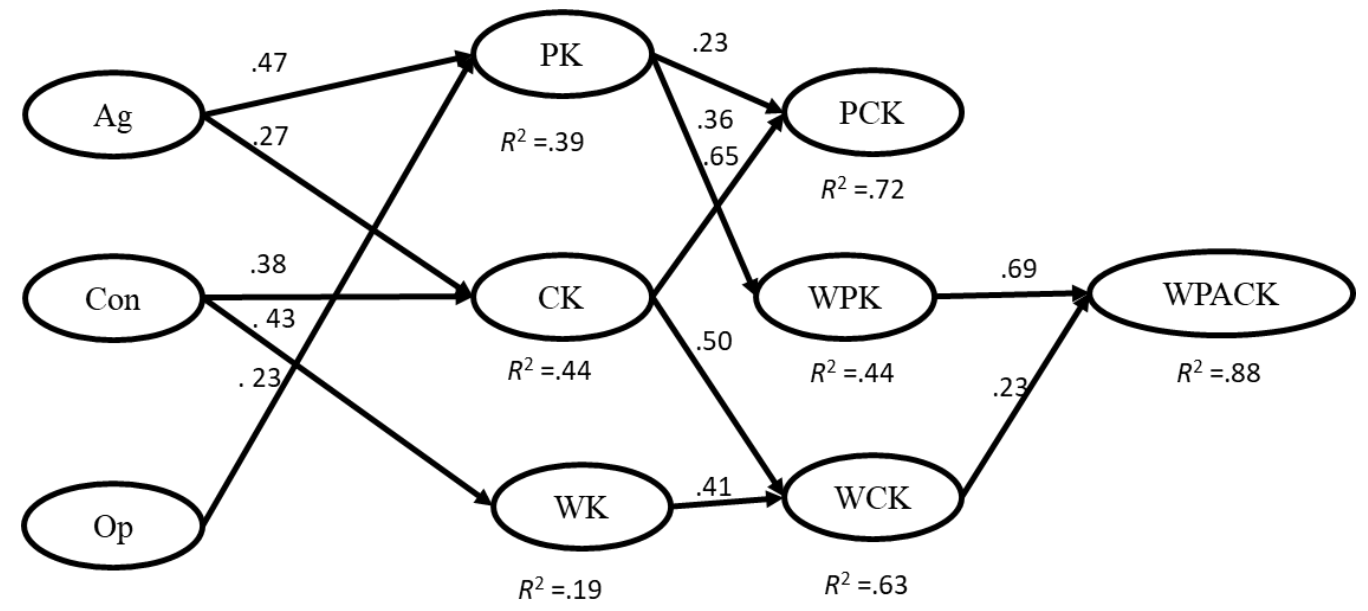

Figure 3. The PLS-SEM corelated TPACK-Web and FFM of personality traits

Table 4. The effect of FFM of personality traits and TPACK-Web

\begin{tabular}{lccccc}
\hline Inter Model & Direct effect & t-Value & p-Values & $95 \%$ internal confident & Effect Size \\
\hline CK $\rightarrow$ PCK & .65 & 7.19 & .00 & {$[.33, .61]$} & .408 \\
CK $\rightarrow$ WCK & .50 & 7.93 & .00 & {$[.33, .54]$} & .408 \\
CK $\rightarrow$ WPACK & .35 & 6.90 & .00 & {$[.24, .44]$} & .000 \\
CK $\rightarrow$ WPK & .11 & 4.33 & .05 & {$[.18, .45]$} & .056 \\
PK $\rightarrow$ PCK & .32 & 4.27 & .00 & {$[.17, .46]$} & .408 \\
PK $\rightarrow$ WPACK & .21 & 4.58 & .00 & {$[.12, .31]$} & .000 \\
PK $\rightarrow$ WPK & .65 & 4.80 & .00 & {$[.19, .46]$} & .057 \\
PCK $\rightarrow$ WPACK & .13 & 2.14 & .03 & {$[.01, .23]$} & .078 \\
WCK $\rightarrow$ WPACK & .23 & 4.70 & .00 & {$[.17, .40]$} & .843 \\
WK $\rightarrow$ WCK & .41 & 6.82 & .00 & {$[.28, .49]$} & .323 \\
WK $\rightarrow$ WPACK & .11 & 3.51 & .00 & {$[.06, .18]$} & .000 \\
WPK $\rightarrow$ WPACK & .69 & 10.31 & .00 & {$[.42, .62]$} & .078 \\
Agreeableness $\rightarrow$ CK & .27 & 3.50 & .00 & {$[.09, .37]$} & .076 \\
Agreeableness $\rightarrow$ PCK & .14 & 4.15 & .00 & {$[.12, .34]$} & .000 \\
Agreeableness $\rightarrow$ PK & .48 & 5.62 & .00 & {$[.24, .52]$} & .244 \\
Agreeableness $\rightarrow$ WCK & .11 & 3.04 & .00 & {$[.04, .17]$} & .000 \\
Agreeableness $\rightarrow$ WPACK & .17 & 3.78 & .00 & {$[.08, .23]$} & .000 \\
Agreeableness $\rightarrow$ WPK & .10 & 3.94 & .00 & {$[.11, .30]$} & .000 \\
Conscientiousness $\rightarrow$ CK & .38 & 4.05 & .00 & {$[.15, .42]$} & .079 \\
Conscientiousness $\rightarrow$ PCK & .13 & 3.52 & .00 & {$[.07, .21]$} & .000 \\
Conscientiousness $\rightarrow$ WCK & .16 & 5.51 & .00 & {$[.17, .35]$} & .000 \\
Conscientiousness $\rightarrow$ WK & .43 & 5.91 & .00 & {$[.23, .46]$} & .229 \\
Conscientiousness $\rightarrow$ WPACK & .14 & 4.17 & .00 & {$[.08, .21]$} & .000 \\
Conscientiousness $\rightarrow$ WPK & .09 & 2.93 & .01 & {$[.04, .15]$} & .000 \\
Openness $\rightarrow$ CK & .16 & 2.16 & .03 & {$[.00, .29]$} & .005 \\
Openness $\rightarrow$ PCK & .15 & 2.89 & .01 & {$[.04, .25]$} & .000 \\
Openness $\rightarrow$ PK & .23 & 3.63 & .00 & {$[.09, .35]$} & .056 \\
Openness $\rightarrow$ WCK & .07 & 2.11 & .04 & {$[.00, .13]$} & .000 \\
Openness $\rightarrow$ WPACK & .11 & 2.83 & .01 & {$[.03, .18]$} & .000 \\
Openness $\rightarrow$ WPK & .13 & 3.12 & .00 & {$[.04, .21]$} & .000 \\
\hline
\end{tabular}

between TPACK-Web and FFM had low effect size, like CK $\rightarrow$ WPACK and Agreeableness $\rightarrow$ CK. Therefore, the low effect size was excluded for the relationship form the model.

The careful identification of the model produces important findings.

1. Overall, from Table 4, there were significant differences among TPACK-Web components and personality traits. 
2. All variables had a positive effect among TPACK-Web variables and FFM of personality (Agreeableness, Conscientiousness, and openness) to the core of TPACK-Web bases (PK, CK, and WK).

3. All of TPACK-Web components were formed similarly with TPACK construction (Pamuk et al., 2015), except WK seems to have the low effect to WPK and also PCK to WPACK (see Figure 3). However, WPK to WPACK had the strongest effect $(\beta=.69, \mathrm{p}<.01)$.

4. FFM of personality traits (Agreeableness, Conscientiousness, Openness) appeared having a high direct effect on the core of TPACK-Web bases (PK, CK, and WK). Agreeableness to PK had the strongest predictor a standardized effect $(\beta=.47, p<.01)$. Meanwhile, FFM of personality traits to second and third level of TPACK-Web bases had a low effect.

\section{DISCUSSION}

In this study, the pre-service teachers had a score over 3 points for TPACK-Web competences. This indicates that they achieved the knowledge need to integrate technology into teaching and learning (Koehler \& Mishra, 2005; Shulman, 1987). Although participants had the lowest score for WK compared with seven components of TPACK-Web, the lowest TK compared with PK and CK also occurred in other researches (Akyuz, 2018; Chen \& Jang, 2018; López-Vargas et al., 2017). Therefore, there is a benefit for the instructor to look at the preservice teacher achievement and its correlation in a web integration course. For example, according to Figure 3, it appears that WK had a high relation to conscientiousness. The instructor might enhance the WK by motiving pre-service teachers to improve the conscientiousness traits in web integration courses.

In addition, Indonesian pre-service teachers' FFM of personality traits had the highest score in agreeableness, while the neuroticism was the lowest mean compared with others. This trend had a similarity to previous researchers (Corcoran \& O'Flaherty, 2018; Kober \& Neuper, 2013; Kokkinos et al., 2015). The finding suggested that the pre-service teachers might have high agreeableness to have the higher emphatic in cooperating with their tasks and the other people, helping other students, attention to their needs, believe in the people (Boyle et al., 2014), and they should have low neuroticism to reduce the person's emotional tendency (Bowles et al., 2014). This was a potent argument to relate between the personality traits and quality of teaching, including technology integration.

For the relationship between TPACK-Web components, the result (Figure 3) appeared to support the TPACKWeb structure considered in Figure 2. It also was showed that $88 \%$ of the variant in WPACK can explain the model. Especially, WPK seems to have the strongest contribution to the WPACK section in stressing the preservice teachers' assistance of web components and capabilities in the education context. Although the previous research (M.-H. Lee \& Tsai, 2010) has not followed the WPK into the TPACK-Web questionnaire, the result in this study had the high relationship as other researchers (Kavanoz et al., 2015; Zhou et al., 2017). This finding suggested that WPK can be included the indicator instrument when the study will be conducted to explore TPACK-Web framework (Brantley-Dias \& Ertmer, 2013).

According to the result, the personality traits (openness, conscientiousness, and agreeableness) more needed was on the level of core teachers' competence (PC, CK, WK), rather than the second level of TPACKWeb (PCK, WCK, WPK). It would be possible to conclude that the instructor needs to grow the traits before integrating the TPACK-Web components in course. For example, focusing on WK, only conscientiousness had a high direct effect explained, $19 \%$. Consistently, the finding was obtained for conscientiousness in past research (Durak \& Senol-Durak, 2014; Rosen \& Kluemper, 2008). Barnett et al. (2015) also claimed that conscientiousness correlated with the perceived and actual use of technology. For PK, the finding appears that Agreeableness had the strongest correlation on PK, this suggested that the instructional activity involves the pre-service teacher to be empathic, avoid conflict, and cooperative (Bowles et al., 2014). Similarly, constructivism, like Vygotsky suggested cooperative learning to activate the zone of proximal development among peers (Slavin, 2018). 


\section{CONCLUSIONS, LIMITATIONS, AND FUTURE DIRECTIONS}

The present study has explored the relationship between TPACK-Web and personality traits, one of the pioneers TPACK-Web and personality correlation that was suggested by (Scherer et al., 2018). The finding showed that pre-service teachers might be good personality traits to have a high quality of web integration in the instructional process. In practice, this study denoted the pre-service teacher to design Web in learning context through a course which presupposes Agreeableness, Conscientiousness, and Openness. Despite the traits had obtained significant correlation and affected the core pre-service teachers' TPACK-Web needs, the endorsement of future research might corroborate this finding.

The present study had two primary limitations and directions for future research. First, the size effect (f2) on two connecting; WK to WPK and PCK to WPACK had a low score below $10 \%$. This might cause no effect for that exogenous latent variable less than .02. Therefore, future research should check the size effect output, and expanding the model could be checked to evaluate the path model. The power analyses could be used to investigate for revision (J. Cohen, 1988). Another method, like qualitative, could be used to employ the diversity method and to lend the confidence of result about the relationship TPACK and personality. Also, future research probably rises the volunteer number in various subject study areas to warrant a significant finding, and the sample can be inferred to a broad population. For this purpose, approach such as mediator and moderator might benefit to explore the other finding applied to pre-service teacher well-being (Dicke et al., 2014).

Author contributions: All authors were involved in concept, design, collection of data, interpretation, writing, and critically revising the article. All authors approve final version of the article.

Funding: The authors received no financial support for the research and/or authorship of this article.

Declaration of interest: Authors declare no competing interest.

Data availability: Data generated or analysed during this study are available from the authors on request.

\section{REFERENCES}

Aiken, L. R. (1985). Three coefficients for analyzing the reliability and validity of rating. Educational and Psychological Measurement, 45(1), 131-142.

Akyuz, D. (2018). Measuring technological pedagogical content knowledge (TPACK) through performance $\begin{array}{lllll}\text { assessment. Computers and 212-225. } & \end{array}$ https://doi.org/10.1016/j.compedu.2018.06.012

Al-Ismail, M., Gedeon, T., \& Yamin, M. (2017). Effects of personality traits and preferences on M-learning. International Journal of Information Technology, 9(1), 77-86. https://doi.org/10.1007/s41870-0170012-0

Alt, D. (2018). Science teachers' conceptions of teaching and learning, ICT efficacy, ICT professional development and ICT practices enacted in their classrooms. Teaching and Teacher Education, 73, 141150. https://doi.org/10.1016/j.tate.2018.03.020

Anvari, F., Richards, D., Hitchens, M., Ali, M., Minh, H., Tran, T., \& Busch, P. (2017). The Journal of Systems and Software An empirical investigation of the influence of persona with personality traits on conceptual design. The Journal of Systems \& Software, 134, 324-339. https://doi.org/10.1016/j.jss.2017.09.020

Barnett, T., Pearson, A. W., Pearson, R., \& Kellermanns, F. W. (2015). Five-factor model personality traits as predictors of perceived and actual usage of technology. European Journal of Information Systems, 24(4), 374-390. https://doi.org/10.1057/ejis.2014.10

Bhagat, K. K., Wu, L. Y., \& Chang, C. Y. (2019). The impact of personality on students' perceptions towards online learning. Australasian Journal of Educational Technology, 35(4), 98-108. https://doi.org/10.14742/ajet.4162 
Biermann, A., Karbach, J., Spinath, F. M., \& Brünken, R. (2015). Investigating effects of the quality of field experiences and personality on perceived teaching skills in German pre-service teachers for secondary schools. Teaching and Teacher Education, 51, 77-87. https://doi.org/10.1016/j.tate.2015.06.005

Bowles, T., Hattie, J., Dinham, S., Scull, J., \& Clinton, J. (2014). Proposing a comprehensive model for identifying teaching candidates. Australian Educational Researcher, 41(4), 365-380. https://doi.org/10.1007/s13384-014-0146-z

Boyle, E. H. O., Forsyth, D. R., Banks, G. C., Story, P. A., \& White, C. D. (2014). A meta-analytic test of redundancy and relative importance of the dark triad and five-factor model of personality. Journal of Personality, 83(6), 644-664. https://doi.org/10.1111/jopy.12126

Brantley-Dias, L., \& Ertmer, P. A. (2013). Goldilocks and TPACK: Is the construct "just right?" Journal of Research on Technology in Education, 46(2), 103-128. https://doi.org/10.1080/ 15391523.2013.10782615

Celik, I., Sahin, I., \& Akturk, A. O. (2014). Analysis of the relations among the components of technological pedagogical and content knowledge (TPACK): A structural equation model. Journal of Educational Computing Research, 51(1), 1-22. https://doi.org/10.2190/EC.51.1.a

Chai, C. S., Tan, L., Deng, F., \& Koh, J. H. L. (2016). Examining pre-service teachers' design capacities for webbased 21st century new culture of learning. Australasian Journal of Educational Technology, 33(November 2016), 1-20. https://doi.org/10.14742/ajet.3013

Chai, C. S., Tan, L., Deng, F., \& Koh, J. H. L. (2017). Examining pre-service teachers' design capacities for webbased 21st century new culture of learning. Australasian Journal of Educational Technology, 33(2), 129142. https://doi.org/10.14742/ajet.3013

Chang, M. C., Shaeffer, S., Al-Samarrai, S., Ragatz, A. B., de Ree, J., \& Stevenson, R. (2014). Teacher reform in Indonesia: The role of politics and evidence in policy making. The World Bank. https://doi.org/10.1596/978-0-8213-9829-6

Chen, Y.-H., \& Jang, S.-J. (2018). Exploring the Relationship Between Self-Regulation and TPACK of Taiwanese Secondary In-Service Teachers. Journal of Educational Computing Research, 64, 073563311876944. https://doi.org/10.1177/0735633118769442

Chua, J. H., \& Jamil, H. (2012). Factors Influencing the Technological Pedagogical Content Knowledge (TPACK) among TVET instructors in Malaysian TVET Institution. Procedia - Social and Behavioral Sciences, 69(Iceepsy), 1539-1547. https://doi.org/10.1016/j.sbspro.2012.12.096

Cohen, A., \& Baruth, O. (2017). Personality, learning, and satisfaction in fully online academic courses. Computers in Human Behavior, 72, 1-12. https://doi.org/10.1016/j.chb.2017.02.030

Cohen, J. (1988). Statistical power analysis for the behavioural sciences. Lawrence Erlbaum Associates.

Corcoran, R. P., \& O'Flaherty, J. (2018). Factors that predict pre-service teachers' teaching performance. Journal of Education for Teaching, 44(2), 175-193. https://doi.org/10.1080/02607476.2018.1433463

Correa, T., Hinsley, A. W., \& de Zúñiga, H. G. (2010). Who interacts on the Web?: The intersection of users' personality and social media use. Computers in Human Behavior, 26(2), 247-253. https://doi.org/10.1016/j.chb.2009.09.003

De Jong, R., Mainhard, T., van Tartwijk, J., Veldman, I., Verloop, N., \& Wubbels, T. (2014). How pre-service teachers' personality traits, self-efficacy, and discipline strategies contribute to the teacher-student relationship. British Journal of Educational Psychology, 84(2), 294-310. https://doi.org/10.1111/bjep.12025

Dicke, T., Parker, P. D., Marsh, H. W., Kunter, M., Schmeck, A., \& Leutner, D. (2014). Self-efficacy in classroom management, classroom disturbances, and emotional exhaustion: A moderated mediation analysis of teacher candidates. Journal of Educational Psychology, 106(2), 569-583. https://doi.org/10.1037/a0035504 
Djigić, G., Stojiljković, S., \& Dosković, M. (2014). Basic personality dimensions and teachers' self-efficacy. Procedia - Social and Behavioral Sciences, 112(Iceepsy 2013), 593-602. https://doi.org/10.1016/j.sbspro.2014.01.1206

Durak, M., \& Senol-Durak, E. (2014). Which personality traits are associated with cognitions related to problematic Internet use? Asian Journal of Social Psychology, 17(3), 206-218. https://doi.org/10.1111/ajsp.12056

Gökçearslan, Ş., Karademir, T., \& Korucu, A. T. (2016). Preservice teachers' level of web pedagogical content knowledge. Journal of Educational Computing Research, 55(1), 70-94. https://doi.org/10.1177/0735633116642593

Horzum, M. B., \& Canan Gungoren, O. (2012). A model for beliefs, tool acceptance levels and web pedagogical content knowledge of science and technology preservice teachers towards web based instruction. Turkish Online Journal of Distance Education, 13(3), 50-69. https://doi.org/10.17718/tojde.11911

Ikpi, E., Enya, B., \& Johnny, A. (2014). The influence of personality trait on the academic performance of secondary school students in Cross River State, Nigeria. Journal Of Humanities and Social Science, 19(3), 12-19.

Jafari Navimipour, N., \& Zareie, B. (2015). A model for assessing the impact of e-learning systems on employees' satisfaction. Computers in Human Behavior, 53, 475-485. https://doi.org/10.1016/j.chb.2015.07.026

Jamil, F. M., Downer, J. T., Pianta, R. C., Jamil, B. F. M., Downer, J. T., \& Pianta, R. C. (2012). Performance, personality, and belie with teacher self-efficacy at program completion. Teacher Education Quarterly, 39(4), 119-138.

Jia, Y., Xu, B., Karanam, Y., \& Voida, S. (2016). Personality, targeted gamification: A survey study on personality traits and motivational affordances. Conference on Human Factors in Computing Systems Proceedings, October 2017, 2001-2013. https://doi.org/10.1145/2858036.2858515

John, O. P., \& Srivastava, S. (1999). The Big Five trait taxonomy: History, measurement, and theoretical perspectives. In Handbook of personality: Theory and research (pp. 102-138). Guilford Press.

Joseph, F., Hair, J., Hult, G. T. M., Ringle, C. M., \& Sarstedt, M. (2017). A Primer on Partial Least Squares Structural Equation Modeling (PLS-SEM). In Thousand Oaks (Vol. 134, Issue 4). SAGE Publications.

Kavanoz, S., Yüksel, H. G., \& Özcan, E. (2015). Pre-service teachers' self-efficacy perceptions on Web Pedagogical Content Knowledge. Computers and Education, 85, 94-101. https://doi.org/10.1016/j.compedu.2015.02.005

Klassen, R. M., \& Tze, V. M. C. (2014). Teachers' self-efficacy, personality, and teaching effectiveness: A metaanalysis. Educational Research Review, 12, 59-76. https://doi.org/10.1016/j.edurev.2014.06.001

Kober, S. E., \& Neuper, C. (2013). Personality and presence in virtual reality: Does their relationship depend on the used presence measure? International Journal of Human-Computer Interaction, 29(1), 13-25. https://doi.org/10.1080/10447318.2012.668131

Koehler, M. J., \& Mishra, P. (2005). What happens when teachers design educational technology? The development of technological pedagogical content knowledge. Journal of Educational Computing Research, 32(2), 131-152. https://doi.org/10.2190/0EW7-01WB-BKHL-QDYV

Kokkinos, C. M., Kargiotidis, A., \& Markos, A. (2015). The relationship between learning and study strategies and big five personality traits among junior university student teachers. Learning and Individual Differences, 43, 39-47. https://doi.org/10.1016/j.lindif.2015.08.031

Lane, W. (2012). The influence of personality traits on mobile phone application preferences. Journal of Economics and Behavioral Studies, 4(5), 252-260. https://doi.org/10.22610/jebs.v4i5.325 
Lee, I. R., \& Kemple, K. (2014). Preservice teachers' personality traits and engagement in creative activities as predictors of their support for children's creativity. Creativity Research Journal, 26(1), 82-94. https://doi.org/10.1080/10400419.2014.873668

Lee, M.-H., \& Tsai, C.-C. (2010). Exploring teachers' perceived self efficacy and technological pedagogical content knowledge with respect to educational use of the World Wide Web. Instructional Science, 38(1), 1-21. https://doi.org/10.1007/s11251-008-9075-4

López-Vargas, O., Duarte-Suárez, L., \& Ibáñez-lbáñez, J. (2017). Teacher's computer self-efficacy and its relationship with cognitive style and TPACK. Improving Schools, 20(3), 264-277. https://doi.org/10.1177/1365480217704263

Marcus, B., Machilek, F., \& Schu, A. (2006). Personality in Cyberspace: Personal web sites as media for personality expressions and impressions. Journal of Personality and Social Psychology, 90(6), 10141031. https://doi.org/10.1037/0022-3514.90.6.1014

McCrae, R. R., \& John, O. P. (1991). An introduction to the five-factor model and its applications. Journal of Personality, 60(2), 175-215. https://doi.org/10.1111/j.1467-6494.1992.tb00970.x

McCrae, R. R., \& John, O. P. (1992). An introduction to the five-factor model and its applications. Journal of Personality, 60(2), 175-215. https://doi.org/10.1111/j.1467-6494.1992.tb00970.x

Mishra, P., \& Koehler, M. J. (2006). Technological pedagogical content knowledge: A framework for teacher knowledge. Teachers College Record, 108(6), 1017-1054. https://doi.org/10.1111/j.14679620.2006.00684.x

Njiku, J., Mutarutinya, V., \& Maniraho, J. F. (2021). Building mathematics teachers' tpack through collaborative lesson design activities. Contemporary Educational Technology, 13(2), 1-14. https://doi.org/10.30935/CEDTECH/9686

Owston, R. D. (1997). Research news and comment: The world wide web: A technology to enhance teaching and learning? Educational Researcher, 26(2), 27-33. https://doi.org/10.3102/0013189X026002027

Ozudogru, M., \& Ozudogru, F. (2019). Technological pedagogical content knowledge of mathematics teachers and the effect of demographic variables. Contemporary Educational Technology, 10(1), 1-24. https://doi.org/10.30935/cet.512515

Pamuk, S., Ergun, M., Cakir, R., Yilmaz, H. B., \& Ayas, C. (2015). Exploring relationships among TPACK components and development of the TPACK instrument. Education and Information Technologies, 20(2), 241-263. https://doi.org/10.1007/s10639-013-9278-4

Perkmen, S., Toy, S., Caracuel, A., \& Shelley, M. (2018). Cross-cultural search for Big Five: Development of a scale to compare personality traits of pre-service elementary school teachers in Turkey and Spain. Asia Pacific Education Review, 19(4), 459-468. https://doi.org/10.1007/s12564-018-9549-2

Redmond, P., \& Lock, J. (2019). Secondary pre-service teachers' perceptions of technological pedagogical content knowledge (TPACK): What do they really think? Australasian Journal of Educational Technology, 35(3), 45-54. https://doi.org/10.14742/ajet.4214

Ringle, C. M., Sarstedt, M., \& Straub, D. W. (2012). A critical look at the use of PLS-SEM in MIS Quarterly. MIS Quarterly (MISQ), 36(1), iii-xiv. https://doi.org/10.3200/JOEB.79.4.213-216

Rosen, P. A., \& Kluemper, D. H. (2008). The impact of the Big Five personality traits on the acceptance of social networking website acceptance of social networking website. Proceedings of the Fourteenth Americas Conference on Information Systems, January 2008. https://doi.org/10.1006/jfan.2001.3890

Scheepers, R. A., Lombarts, K. M. J. M. H., van Aken, M. A. G., Heineman, M. J., \& Arah, O. A. (2014). Personality traits affect teaching performance of attending physicians: Results of a multi-center observational study. PLoS ONE, 9(5), e98107. https://doi.org/10.1371/journal.pone.0098107 
Scherer, R., Tondeur, J., Siddiq, F., \& Baran, E. (2018). The importance of attitudes toward technology for preservice teachers' technological, pedagogical, and content knowledge: Comparing structural equation modeling approaches. Computers in Human Behavior, 80, 67-80. https://doi.org/10.1016/j.chb.2017.11.003

Schmidt, D. A., Baran, E., Thompson, A. D., Mishra, P., Koehler, M. J., \& Shin, T. S. (2009). Technological pedagogical content knowledge (Track): The development and validation of an assessment instrument for preservice teachers. Journal of Research on Technology in Education, 42(2), 123-149. https://doi.org/10.1080/15391523.2009.10782544

Seal, K. C., \& Przasnyski, Z. H. (2001). Using the World Wide Web for teaching improvement. Computers and Education, 36(1), 33-40. https://doi.org/10.1016/S0360-1315(00)00049-X

Shulman, L. S. (1986). Those who understand: Knowledge growth in teaching. American Education Research Association, 15(2), 4-14. https://doi.org/10.1017/СBO9781107415324.004

Shulman, L. S. (1987). Knowledge and teaching: Foundations of the new reform. Harvard Education Review, 57(1), 1-21.

Sife, A., Lwoga, E., \& Sanga, C. (2007). New technologies for teaching and learning: Challenges for higher learning institutions in developing countries. International Journal of Education and Development using ICT, 3(2), 57-67. https://www.learntechlib.org/p/42360/

Slavin, R. E. (2018). Educational psychology: Theory and practice (12th ed.). Pearson Education.

Thohir, M. A., Jumadi, J., \& Warsono, W. (2020). Technological Pedagogical Content Knowledge (TPACK) of pre-service science teachers: A Delphi study. Journal of Research on Technology in Education. Published online: 16 October 2020. https://doi.org/10.1080/15391523.2020.1814908

Ulug, M., Ozden, M. S., \& Eryilmaz, A. (2011). The effects of teachers' attitudes on students' personality and performance. Procedia - Social and Behavioral Sciences, 30, 738-742. https://doi.org/10.1016/j.sbspro.2011.10.144

Walkowiak, S., Foulsham, T., \& Eardley, A. F. (2015). Individual differences and personality correlates of navigational performance in the virtual route learning task. Computers in Human Behavior, 45, 402410. https://doi.org/10.1016/j.chb.2014.12.041

Wu, W., Chen, L., Yang, Q., \& Li, Y. (2019). Inferring students' personality from their communication behavior in web-based learning systems. International Journal of Artificial Intelligence in Education, 29(2), 189216. https://doi.org/10.1007/s40593-018-00173-9

Xie, H., Chu, H. C., Hwang, G. J., \& Wang, C. C. (2019). Trends and development in technology-enhanced adaptive/personalized learning: A systematic review of journal publications from 2007 to 2017. Computers and Education, 140(July 2018), 103599. https://doi.org/10.1016/j.compedu.2019.103599

Zhou, Y., Chai, C. S., Liang, J. C., Jin, M., \& Tsai, C. C. (2017). The relationship between teachers' online homework guidance and technological pedagogical content knowledge about educational use of web. Asia-Pacific Education Researcher, 26(5), 239-247. https://doi.org/10.1007/s40299-017-0344-3

Correspondence: M. Anas Thohir, Universitas Negeri Malang, Indonesia. E-mail: anas.thohir.fip@um.ac.id 


\section{APPENDIX 1}

\section{The Questionnaire of WPACK and FMM}

\begin{tabular}{l} 
Indicators Statements \\
\hline PK \\
I was able to develop a plan for implementing learning based on learning objectives \\
I was able to choose a model / approach to learning in the classroom (e.g., collaborative learning, \\
direct instruction, inquiry learning, and problem / project-based learning) in accordance with the \\
material and learning objectives that I want to achieve \\
I was able to choose the right type of evaluation to assess the performance (cognitive, skill, and \\
affective) of students in the class \\
I was able to adapt my teaching style to different students
\end{tabular}

CK

I understand the concepts, principles, laws, material structures of your field material $\quad .66$

I understand scientific inquiry, experimental processes, and social perspectives $\quad .77$

I have various examples of how your field material is applied in everyday life $\quad .64$

I have problem solving skills in your field material $\quad .66$

WK

I was able to insert YouTube videos or scrip formulas or mathematical equations into a blog or web

I often make web or blog modifications as I want

.71

.74

.72

I was able to design a blog or website is easy to use

PCK

WPK

I was able to select effective learning approaches to teach thinking skills and guide students to learn in your field material

I could develop your field material tests according to the learning objectives

.64

I was able to choose the appropriate evaluation instrument to measure the achievement of student your field material understanding and performance

I was able to map students who understood your field material and your field material misconceptions from the diagnostic tests that I developed

I can develop the web for the purposes of designing learning devices (lesson plant and Textbooks) I can develop the web for the application of learning with certain learning strategies such as collaborative learning, direct instruction, inquiry learning, and problem / project-based learning I was able to develop the web to evaluate student achievement in learning

I was able to use web technology to understand the concepts, laws, material structure in your field material, and apply them

I was able to adapt a web to understand the concepts, material structure in your field material, and apply them

I was able to explore the web to find out the concept in your field material structure, and apply it

WPACK

I could adapt web technology to evaluate the achievement of understanding your field material and student performance

I advertise the web as a technology used in carrying out learning with learning strategies such as collaborative learning, direct instruction, inquiry learning, and problem / project-based learning I adapted several web-based learning strategies in the classroom such as collaborative learning, direct instruction, learning inquiry, problem / project-based learning I was able to develop learning such as collaborative learning, direct instruction, inquiry learning, and web-based problem / project-based learning on your field material

\section{Agreeableness}

I see myself as someone who is helpful and unselfish with other people

I see myself as a forgiving person

I see myself as a person who is caring and kind to almost everyone 


\begin{tabular}{ll}
\hline $\begin{array}{l}\text { Indicators } \\
\text { Statements }\end{array}$ & $\begin{array}{c}\text { Factor } \\
\text { loadings }\end{array}$ \\
\hline $\begin{array}{l}\text { Extraversion } \\
\text { I see myself as a talkative person } \\
\text { I see myself as a quiet person } \\
\text { I see myself as a person who produces a lot of enthusiasm }\end{array}$ & -.79 \\
Openness $\quad$ I see myself as an original person, emerging with a new idea & .78 \\
I see myself as an intelligent person, a deep thinker & .79 \\
I see myself as a person who has an active imagination & .84 \\
I see myself as an inventive person & .74 \\
I see myself as a mirror person, playing with ideas & .84 \\
I see myself as a depressed person & .82 \\
I see myself as a person who becomes tense & .72 \\
I see myself as a person who worries a lot & .87 \\
I see myself as a person who becomes depressed & .72 \\
I see myself as an easy-going person & .76 \\
I see myself as a person who is a reliable worker & .72 \\
I see myself as a person who survives until the task is complete \\
I see myself as an efficient person
\end{tabular}

